UDC: 930.2"Сосенко"

\author{
Svitlana Blashchuk, \\ Candidate of Historical Sciences (Ph.D. in History), \\ Researcher, Institute of History of Ukraine \\ National Academy of Sciences of Ukraine (Ukraine, Kyiv), \\ blashchuks@gmail.com, \\ orcid.org/0000-0003-1430-6353
}

\title{
"THE KAPTUR COURTS" [kapturovi sudy] BY PETRO SOSENKO: HISTORY OF ONE STUDYING CASE DURING THE GREAT TURN TIMES*
}

In historiographical studies are useful not only published academic papers, but planned and not completed indeed researches projects too, as well as lost works of historians. As for the later point, we have no approximate statistical information, despite some attempt to generalize these information are made periodically.

Based on the logics of historical development of Ukraine in XX century, one can conclude, that the most amount of the lost researching projects accrue to $1920^{\text {th }}$ and $1930^{\text {th }}$. It was the period of the totalitarian regime consolidation, following the control of Communist Party over academic researches and repressions against the academicians.

Searching, finding and renewal of the lost projects are important for the contemporary Ukrainian historiography. It allows the deeper comprehension of the situation with scholarly researches during the first three decades of XX centuries, as well as the condition of the Ukrainian society of that time. In particular, the newly found texts can impact the advancement of researching and can point towards methodology and trends of further investigations or even can outline the primary sources depository that was completely perished during the Soviet period.

The article considers the scholarly investigations of the kaptur courts by Petro Sosenko. The Commission for the Study of the History of Western-

* Preparation of this article was made possible thanks to the generous support of the Alexander and Helen Kulahyn Endowment Fund (Canadian Institute of Ukrainian Studies, University of Alberta). 
Ruthenian and Ukrainian Law (functioning in $1920^{\text {th }}$ and being chaired by Mykola Vasylenko) paid the attention to the evidently insufficient state of the mentioned subject researches on the basis of materials of Ukrainian territories of the Early Modern Period. They tasked a new post graduate student Petro Sosenko with investigation of this subject. He belonged to the circle of returned migrants and entered the post graduate study after the order of the People's Commissariat of education of Ukrainian Socialist Soviet Republic. He had got experience of academic work and academic management before his migration to the Soviet Union, he was editor in chief of the Lviv almanac "Science and Literature", and he wrote at least one article on the history of Ukrainian Law.

P. Sosenko used sizable primary sources base for his post graduate studying. He was the first person who had exceptional chance to investigate the whole array of the historic acts of Kyiv Central Archive of Ancient Acts. His work "Origin of Kaptur Courts and Their Development at Right-Bank Ukraine in the $16^{\text {th }}$ Century" is lost now. Neither his manuscript nor the text prepared for publication in "The Proceedings of the Commission for the Study of the History of Western-Ruthenian and Ukrainian Law " survived, any more than a special monograph. The study was prepared and even defended, rather with some problems. It's publication as a single issue or as an article in an academic collected works/periodical was disturbed by the policy of terror and repressions. But a typing of the promotional report points/thesis by P. Sosenko survived, which he made at the a meeting of the Commission for the Study of the History of Western-Ruthenian and Ukrainian Law in January, 4, 1930. These points/thesis was found in the Mykola Vasylenko's personal fonds being held in the Manuscript Institute of the V. Vernadskyi National Library of Ukraine. They are published in the present article.

Keywords: kaptur court, interregnum, academic paper, history of law, the lost paper, the Commission for the Study of the History of Western-Ruthenian and Ukrainian Law.

Світлана Блащук, кандидат історичних наук, науковий співробітник, Інститут історії України Національної академії наук України (Україна, Київ), blashchuks@gmail.com, orcid.org/0000-0003-1430-6353

\section{"КАПТУРОВІ СУДИ" ПЕТРА СОСЕНКА: ІСТОРІЯ ОДНІЄЇ СТУДІЇ ЧАСІВ "ВЕЛИКОГО ПЕРЕЛОМУ"}

Для історіографічних студій важливі не лише оприлюднені наукові розвідки, а й заплановані, однак нереалізовані дослідниџькі проекти, а також втрачені праці істориків. Чи не найбільше таких проектів припадає на 1920-1930-ті рр. Саме у цей час відбувалося утвердження тоталітарного режиму, що супроводжувалося встановленням компартійного контролю як над науковими дослідженнями, так і репресіями проти вчених. 
Пошук і відновлення втрачених проектів вельми важливі для сучасної вітчизняної історіографії. Це дасть змогу глибше зрозуміти не лише стан наукових студій першої третини ХХ ст., а й тодішнього украйнського суспільства загалом. Частково віднайдені тексти щонайменше зможуть надати нового імпульсу дослідженням, підказати методологію, напрями подальших пошуків, а також указати на джерельну базу, безповоротно втрачену в радянський час.

Статтю присвячено науковій розвідці Петра Сосенка про каптурові суди. Комісія для виучування історії західноруського та вкраїнського права, що діяла в 1920-х рр. під керівництвом Миколи Василенка, звернула увагу на явно недостатній стан досліджень зазначеної тематики для українських теренів ранньомодерного часу. Розробку цієї проблеми доручили новому аспірантові Петру Сосенку. Він належав до кола "поворотців" і вступив до аспірантури за розпорядженням Народного комісаріату освіти УСРР. До переїзду у «країну Рад» уже мав досвід наукової та науково-організаційної роботи: очолював редакцію львівського часопису "Наука й письменство", написав щонайменше одну статтю з історії українського права.

П. Сосенко у своїх аспірантських студіюваннях користувався грунтовною джерельною базою. Він здобув унікальну можливість першим опрацювати цілісний масив актів у Київському центральному архіві давніх актів. Ним була підготовлена праця під назвою "Походження й розвиток каптурових судів на Правобережній Україні (XVI cm.)", друк якої мав відбутись на сторінках "Праць Комісії для виучування історії західноруського та вкраӥнського права". На превеликий жаль, на сьогодні нам не вдалося віднайти ні рукопис, ні запланований до друку текст. Не відомо також, чи було підготовлено окреме монографічне дослідження. Проте нам вдалося встановити, що робота П. Сосенком була виконана та (не без проблем) захищена. В Інституті рукопису Національної бібліотеки України ім. В. Вернадського (особовий фонд голови «Комісії для виучування історії західноруського та вкраїнського права» акад. М. Василенка), зберігається машинопис написаних П. Сосенком тез промоційної доповіді, що їі він виголосив 4 січня 1930 р. на одному із засідань "Комісії...". Опублікувати окремим відбитком працю П. Сосенка або ж у форматі статті у науковому збірнику завадила репресивна політика радянських каральних органів. Зазначені тези публікуються у додатку до нашої статmі.

Ключові слова: каптуровий суд, безкоролів'я, наукова праця, історія права, втрачена праця, Комісія для виучування історії західноруського та вкраїнського права.

The subject of kaptur courts, special courts which were organized and were functioning during the period of interregnum in Rzecz Pospolita does not belong to the well-researched themes of Ukrainian historiography (Starchenko, 2009: 256). So this theme came in view of an academician Mykola Vasilenko, the 
member of the All-Ukrainian Academy of Sciences (hereafter AUAS) in the 20 th $20^{\text {th }}$ century. M. Vasylenko was a chairman of the Commission for the Study of the History of Western-Ruthenian and Ukrainian Law of AUAS, so he paid a special attention to the under-investigated issues of the history of Ukraine. It was under his leadership that the investigations on the history of Ukrainian law became the priority area of the activity of the Commission. The elder generation of the Commission members consists of the well-known specialists following their investigations on the chosen themes. In contrary, the interests of the young researchers who started their work in the Commission were focused in the direction considered to be important. So in 1926 M. Vasylenko proposed a new and unexplored subject for investigation for a new postgraduate student Petro Sosenko. It was "Origin of Kaptur Courts and Their Development at Right-Bank Ukraine in the $16^{\text {th }}$ Century".

Unfortunately, the manuscript of this work seems to be lost, at least it was not found in any archive of Ukraine till now. But existence of the work is proved with the fact it was discussed and recommended for publishing at meetings of the Commission.

Ukrainian historians paid attention to the question of the forbidden and annihilated publications as well as partly implemented projects not ones. As in exact paper by Serhiy Bilokin ("Prohibited Publications at the Stage of Layout or Destroyed Circulations (1920-1941)") (Bilokin', 2004: 554-602) were a number unique editions annihilated in the first half of the 20th century because of the political reasons. However he omitted the publications of the Commission for the Study of the History of Western-Ruthenian and Ukrainian Law in his article.

It was Ihor Usenko, who contributed greatly to the study of the legal heritage of All-Ukrainian Academy of Sciences (hereafter AUAS) as well as the academic heritage of Mykola Vasylenko. He noted that the legacy of AUAS is traditionally reduced to the published materials of academic publications, such as "The Commission Proceedings for Studying Customary Ukrainian Law", "The Commission for the Study of the History of Western-Ruthenian and Ukrainian Law", "The Commission Scientific Researches and Articles of the Soviet Law", "Notes of the Social Economic Department". Additionally there is a number of monographs, archaeographical and other juridical publications which were published as the series "Social Economic Department Collection". Some articles on the history of Ukrainian law and justice were published in the collected works in commemoration of the Members of Ukrainian Academy of Sciences Dmytro Bahaly and Mykhailo Hrushevsky as well as in the journal "Ukraine", professional law journals "Soviet Justice Herald", "Red Law" and other publications (Usenko, 2013: 6-7).

Hence the works prepared to publication but not published or published but further confiscated and annihilated also are the part of historiography. So I. Usenko made considerable investigation and found out a number of the Commission members' works, which hadn't been published or had been destroyed on the stage 
of layout due to various reasons (Usenko, 2013: 6-14). But I. Usenko didn't include the contribution of Petro Sosenko to the development of Ukrainian law and jurisprudence historiography. The present paper aims to eke out this lacuna with presenting the results of our researches about Petro Sosenko's contribution to the Ukrainian law and jurisprudence historiography.

Petro Sosenko was born in 1900 in the village Duliby (Bibrsk region) in the family of the Greek-Catholic priest and well-known Ukrainian ethnologist Xenophont Sosenko (ЦДАГО України, ф. 263, оп. 1, спр. 66457, т. 21, арк. 1а.). He got his education in Lviv at first in a gymnasium and then entered Lviv University (Dilo, 1918: 3). He had to interrupt his education because of the First World War, he was conscripted to the Galician army and later he was captured. After his liberation he returned to Lviv but he could not resume his studying at the university, therefore he entered the one year courses of the Prosvita Society. When Ukrainian Secret University came into existence in Lviv he entered the faculty of law (Mudryi, 2011: 36-41). In 1924 he was arrested by Polish authority through his participation in a demonstration on the occasion of the public figure Olga Besarab's funeral (ЦДАГО України, ф. 263, оп. 1, спр. 66457, т. 21, арк. 2-3).

He graduated from the university with the proceeding about the Soviet state system and constitution. He was noticed. AUAS academician and the active member of Shevchenko Scientific Society Stanislav Dnistryansky spoke positively about Sosenko in his article "In Defense of Ukrainian Science of Law" (Dilo, 1924: 2). But Volodymyr Galan, who became later a well-known diaspora figure, criticized Petro Sosenko's work quite acutely (Dilo, 1929: 1).

After several attempts to deal with publishing business he decided to move to sub-Soviet Ukraine.

In 1925 he pretended to be a former expatriate named Anton Dosenko to move to Kharkiv first and then to Kyiv. In 1926 he met and married Maria the daughter of the priest Mykola Shchepaniuk.

At first he worked in Kharkiv as an assistant of the secretary for the Criminal Cassation Board of the Supreme Court of Ukrainian Socialist Soviet Republic. However Petro Sosenko obviously disliked the practical aspects of jurisprudence. Instead he had a steady interest in the law history studies.

So he gained for himself a business trip to Kyiv for academic research reimbursed by the People's Commissariat of Education of the Ukrainian Socialist Soviet Republic. In fact it was a permission to enter the postgraduate study (ЦДАГО України, ф. 263, оп. 1, спр. 66457, т. 21, арк. 2 зв.; Sokolovskyi, 1999: 197).

Since 1926 Petro Sosenko became a post-graduate student of the Commission and got a special scholarship from Uprnauka, the Higher Administrative Office of Soviet Ukrainian science (Okynshevych, 1929: XVII).

He grew up in academic community, and he ready comprehended the specifics of academic research. Therefore he began to work willingly.

At his early postgraduate activity he already had an experience of academic 
researches. When he lived in Lviv in 1924 he became the editor-in-chief for Lviv "young Ukrainian generation" journal "Science and Literature" (Ukrainski chasopysy, 2003: 445), that was supposed to rally the "young writers' forces" (Nauka i pysmenstvo, 1924: 3 ).

The first part of his academic research "Ethnological Origins of the Old Ukrainian Law (Experiments with the Beginnings of Ukrainian Legal Culture)" was published in this edition (Sosenko, 1924: 23-42; Okynshevych, 1929: XVII).

Even at the first meetings of the Commission which Petro Sosenko attended as a post-graduate student he actively came in on the consideration, took part in the discussions, made additions and proposals (Protokoly Komisii, 1927: 466-500).

The theme of his research was the ethnological method in the history of Ukrainian law, the beginnings of local communities of the old Ukrainians in ethnological interpretation in conjunction with the development of organic communities and the development of courts of interregnum (kapturowi) on the RightBank Ukraine (Okynshevych, 1929: XVI).

In meetings on May 10, and May 21, 1927 P. Sosenko made a report "Ethnological Method for the History of Ukrainian Law" (Protokoly Komisii, 1927: 495497). The minutes of the meetings record the fact that his report faced critique of his colleagues, they were displeased by his speech and immediately pointed out abstractedness of his statements as well as the vagueness of his conclusions (Protokoly Komisii, 1927: 495-497). The presentation of the material was "unsystematic, verbose, evidently incomprehensible to the author himself" (ЦДАМЛМ України, ф. 542, оп. 1, спр. 46, арк. 315).

However the young researcher was rather skeptical in respect of his senior colleagues' criticism and comments. The reproaches they addressed to him were fair, but P. Sosenko himself was a kind of "persistent" person and was not about to give up. He promised to show the results of his research via a particular material then and he did it shortly. But this work failed as well. And he simply stopped this work and focused his interest on other theme.

As for his postgraduate thesis on the kaptur courts he had a large aria for investigations, because actually nobody worked with the concerning archive materials of Kyiv Central Archive of Ancient Acts (now it is the Central State Historical Archives of Ukraine in Kyiv).

The fact should be noted that since 1920-th till 1930-th a large number of archival documents and acts became accessible for researchers, the documents were restored, conserved, the archive fonts were ordered in the system and catalogized. All this became possible thanks to the efforts of the Archive Director V. Romanovsky. So P. Sosenko received a unique opportunity to be the first in order to investigate a whole array of acts. It had become a certain academic impact but this fact hadn't significant impact on his work, as it is evident from the results. 
Sosenko's years of postgraduate studies were rather peculiar. The explanation for this statement is found in the memories of N. Polonska-Vasylenko (ЦДАМЛМ України, ф. 542, оп. 1, спр. 46). Since the first months of his work the members of the Commission "had pointed out his laziness and inability for scientific work" (ЦДАМЛМ України, ф. 542, оп. 1, спр. 46, арк. 314). As I. Cherkasky wrote in his memories about M. Vasylenko, the later academician had a soft character and due to him the meetings of the Commission always had been held in the favorable academic atmosphere (ЦДАМЛМ України, ф. 542, оп. 1, спр. 46, арк. 312). Тhe minutes of the meeting where the report of P. Sosenko was discussed, prove M. Vasylenko tried to smooth all the "sharp angles" being arisen during the discussions. I. Cherkasky mentioned only two cases of sharp disputes and contradictions. One of them concerned "the post-graduate student Sosenko's contribution who even refused to get through a colloquium on his speciality" (ЦДАМЛМ України, ф. 542, оп. 1, спр. 46, арк. 314).

In the span of the years of postgraduate studies P. Sosenko published only one small work. It was a review of Joseph Vydaevych's publication (Sosenko, 1929: 493-500).

In 1927 0. Malynovsky (the academic supervisor of P. Sosenko) made record in the scientific annual report that his postgraduate had advanced in researching of various themes except his post-graduate thesis (ЦДАГО України, ф. 263, оп. 1, спр. 66457, т. 30, арк. 5-5 зв.). The supervisor expected his postgraduate student would be able to finish his announced postgraduate thesis. However his expectations never had been realized.

When the term of postgraduate training for P. Sosenko expired, his academic supervisor I. Malynovsky refused to continue his supervising because the postgraduate could not achieve any results (ЦДАМЛМ України, ф.542, оп. 1, спр. 46, арк. 315).

M. Vasylenko tried to save the situation. He asked S. Borysenko and L. Okynshevych to help the post-graduate student to streamline somehow his materials at least. By that time the members of the Commission had already believed that he would be unlikely to handle the materials on his own. The report of P. Sosenko about ethnological method of researches proved these worse expectations.

Despite that situation, in May 1928 P. Sosenko asked the Commission for academic trip to Bukovyna, Zakarpattya and Galicia for researching the "home communities" in local archives (ІР НБУВ, ф. 40, оп. 1, од. зб. 682, арк. 1). In his application he also emphasized that he intended to complete his postgraduate program in summer of 1929 and to begin studying of another theme. This fact was recorded in the Commission plan for 1928/1929: "Postgraduate student P. Sosenko should complete his postgraduate experience in his 1928/1929 years and the Commission intended to test his knowledge in a special interview. Sosenko researches the subject of primitive law and had to present it as his postgraduate work" (ІР НБУВ, ф. 40, оп. 1, од. зб. 239, арк. 2). 
P. Sosenko wrote his thesis on kaptur courts at last. On January 4, 1930 the promotional defense of his thesis took place. S. Ivanytsky (IР НБУВ, ф. 40, оп. 1, од. зб. 671, 5 арк.) and V. Romanovsky (IP НБУВ, ф. 40, оп. 1, од. зб. 678, 4 арк.) were the official academic referee of the thesis and additionally I. Cherkasky (IР НБУВ, ф. 40, оп. 1, од. зб. 162-237, арк. 1) was unofficial reviewer.

All the referees approved the postgraduate work in general, they recognized its scientific value. First of all the reviewers noted the fact of the archival material investigation made by a young researcher: "The strength of the archival materials which never had been printed and which the author used imposes on the whole his work a special colour that is inherent to all the works which are based on the new materials. Namely such works compel the authors to quote the archival materials widely and to add the most important documents at the end of the work as addendum. Therefore this fact sometimes affects in a bad way on the architectonics of the work, complicates the verification of evidences and makes the reader be contingent on the author who may dispose his critical apparatus freely as well as the whole system of his evidences" (ІР НБУВ, ф. 40, оп. 1, од. зб. 678, арк. 2).

Though the comments of the referees were considerable and they influenced the impressions concerning the post-graduate work but they were veiled. This is true especially for the comments that arrangement of the thesis chapters was chaotic and the actual conclusions were absent in the thesis (IР НБУВ, ф. 40, оп. 1, од. зб. 678, арк. 3-4).

The rather friendly air of the thesis defense was not haphazard. Later M. Vasylenko would call it his own mistake because he believed that P. Sosenko would leave the academy after his dissertation defending and obtaining the scientific researcher degree; thus the Commission would be able to dispose of him. Nonetheless after the thesis defence procedure P. Sosenko made every effort for to remain a regular staff member of the academic institution and became (according to M. Vasylenko) "a ballast who does nothing but occupies a somebody's place" (ЦДАМЛМ України, ф. 542, оп. 1, спр. 46, арк. 316).

S. Borysenok became an irreconcilable opponent of the thesis defence; initially he even didn't intend to be present during the P. Sosenko's dissertation defence, as he seems to have foreseen the results. Nevertheless he joined the discussion and voted "pro", in accordance to the minutes of meeting (IP НБУВ, ф. 40, оп. 1, од. зб. 162-237, арк. 2).

The points of criticism by V. Romanovsky, S. Ivanytsky and I. Cherkasky are rather similar; they emphasized the same mistakes of this thesis. Everybody concluded that "the author had a various material at his disposal, but he was not able to use it properly" (ІР НБУВ, ф.40, оп. 1, од. зб.678, арк. 3 зв.). In their reviews for thesis (deposited in the personal fonts of M. Vasylenko at present) all their comments are detailed with concrete examples from the thesis under 
consideration (ІР НБУВ, ф. 40, оп. 1, од. зб. 671, 5 арк.; ІР НБУВ, ф. 40, оп. 1, од. зб. 678,4 арк.).

As for the main points of their criticism, they can be summarized as the next: significant faults of the thesis composition (V. Romanovsky pointed out "inconsistency and illogicality of the thesis"), the academic reviewers emphasized the thesis must be re-made thoroughly. It makes sense that the Chapter XIII to be removed at the beginning of the thesis, since it influences understanding of further chapters. A few of chapters the history of kaptur courts and their structure are confused, but each of these issues should be highlighted separately. The author uses the material chaotically, therefore his certain sentences remain completely without argumentation (additionally every statement must be confirmed by the documents, the author's evidences sometimes contradict to what he wants to prove); there are no conclusions in the thesis. In accordance to the opinion by I. Cherkasky, each issue should be considered within the context of all cases of interregnum courts, so such approach enabled study of the development of such courts. But the author of the dissertation studied in details the first case of the interregnum court (16-th century) only. As for the second and the third cases of interregnum courts, he made the common researching of them. Such approach was completely inconsistent (ІР НБУВ, ф. 40, оп. 1, од. зб. 162-237, арк. 1-1 зв.).

It was necessary to take the kapturs as the basis for subject of researches only, and the judiciary practice should be used for explication only. However the author once again gives preference to legal matters. It is noteworthy that kaptur courts replaced some previous courts, there was no revolution and only the form of the court had been changed. The fact that the author considers the ordinary kaptur law was obviously just the use of previous practice (ІР НБУВ, ф. 40, оп. 1, од. зб. 162-237, арк. 1-1 зв.).

At the end of the discussion P. Sosenko responded to some remarks only, as he was short of time. In particular he did not recognize the criticism of the thesis design flaws to be fair. He also noted that all his statements were supported by the aappropriate references but he did not specify which ones exactly. He additionally emphasized that he could not give more substantive conclusions since his work considers the 16th century (!) only (ІР НБУВ, ф. 40, оп. 1, од. зб. 162-237, арк. 1). This means he actually agreed with the fact that he did not research the kaptur courts systematically but only isolated moments had been torn apart from the general historical context. At the subsequent meetings he will continue to "respond" to the comments of his opponents. It looks quite interesting that in the middle of February, when reading the protocols of the previous meetings, P. Sosenko will ask to add to them his answers to S. Ivanytsky (IP НБУВ, ф. 40, оп. 1, од. зб. 162-237, арк. 6).

Summing up the discussion the Commission unanimously acknowledged the work to be satisfactory for granting its author the title of academic fellow, and they decided to refer the case to the authorized representative of Uprnauka 
(Supreme Science Body of Ukraine) and ask for the approval of P. Sosenko as a researcher (ІР НБУВ, ф. 40, оп. 1, од. зб. 162-237, арк. 2).

Afterwards we can follow rather interesting behavior of P. Sosenko. Being no longer a graduate student, he began to criticize his colleagues and especially those ones who once expressed their remarks to him. In January 23, 1930 S. Borysenok had a report about the custom in ancient Ukrainian law at the meeting. P. Sosenko was the first to speak in the discussion and noted: "the conclusions are baseless and the work has the character of a sketch" (ІР НБУВ, ф. 40, оп. 1, од. зб. 162237, арк. 2б). Thus and so I. Cherkasky say that "Sosenko makes remarks in the same way which he had been previously reproached for" and other members of the Commission supported this view (ІР НБУВ, ф. 40, оп. 1, од. зб. 162-237, арк. 2б зв.). In November 1930 during candidacy for the post of the Commission staff, two candidates (P. Sosenko and V. Gryshko) were discussed (IP НБУВ, $\phi .40$, оп. 1, од. зб.162-237, арк. 26). All members unanimously supported the latter nominee despite the fact that he began to work for the Commission much later (Okynshevych, 1929: XVIII). P. Sosenko was entrusted with certain tasks from the Commission such as to run a workshop of history in the printing house, there were commissions which did not require special abilities and knowledge of the performer (ІР НБУВ, ф. 40, оп. 1, од. зб. 162-237, арк. 34). In the report about his academic trip to Zhytomyr in early 1931, P. Sosenko demonstrated once again his not exactly active attitude to his new academic investigations. During his academic trip he didn't set a goal of his investigation so he had nothing to report on. However he announced a new subject of his researches at the time. It was the history of the Soviet law before codification (ІР НБУВ, ф. 40, оп. 1, од. зб. 162237, арк. 34).

But in any case Petro Sosenko with the help of his colleagues had done a great job and involved a large array of archival materials. In the fonds of M. Vasylenko only the compendium of his theses is stored, therefore currently it is difficult to say in what form the text of this work existed. The further fate of it is rather complicated. At the beginning of the 1930's P. Sosenko's work "Kaptur Courts of the 16th Century" was included into the Commission plan, even its volume of ten printed sheets was indicated (ІР НБУВ, ф.40, оп. 1, од. зб. 238, арк. 2). But it never had been published, as well as the articles of the indicated theme.

Some fragments of P. Sosenko's work might be published in the ninth issue of the "Commission Proceedings...". However this issue remained in the Commission plans only. Now we only know the previous content. It was planned to collect and to complete the periodical in a rather short term, the issue might be sent for printing within May 23 till December 1, 1930 (ІР НБУВ, ф. 40, оп. 1, од. зб. 162237, арк. 17). If the Commission made a plan for this publication, we are more than convinced that the text actually existed and the members of the Commission saw it. It is proved in the protocols of the Commission meetings and in N. Polonska-Vasylenko's memories. 
At the same time an urgent problem with the seventh issue of "Proceedings ..." arose, which might be resolved quickly. M. Slabchenko had been arrested in 1929 and it was necessary to replace his article in a short time by the material that had been already prepared for publication. N. Polonska-Vasylenko notes that it was decided to replace the article with the paper "Kaptur Courts in Ukraine" of P. Sosenko (Polonska-Vasylenko, 1948: 53; Polonska-Vasylenko, 1962: 109). But in the process of the replacement preparing P. Sosenko was also arrested and exiled. Thereon the Commission was closed as well. Therefore in fact the collected papers were not published (Polonska-Vasylenko, 1948: 53). But there were pilot copies. L. Okinshevych notes in his memories: "While understanding the hopelessness of the $7^{\text {th }}$ issue publication I tried to keep it" for the best of times." Before sending a printed book to Glavlit (a Soviet censorship), I had taken two copies of it from the print shop.... I left one of the copies for myself and the second one handed over to M. Vasylenko" (Okinshevych, 1995: 42-43). A copy of L. Okinshevych burned during a fire in Smolensk but the fate of the second copy is unknown. L. Okinshevych notes that according to N. Polonska-Vasylenko's memories this copy together with the library of M. Vasylenko was transferred to the library of the Academy of Sciences (Okinshevych, 1995: 43). N. Polonska-Vasylenko wrote about it in 1948 (Polonska-Vasylenko, 1948: 53). Later in her article "Historical Science in Ukraine for the Soviet Era and the Fate of Historians" she wrote more details about the replacement of articles.

But it is unknown whether this copy got to the library as the transference of documents was held in difficult conditions. The fate of M. Vasylenko's materials is difficult to follow. After the death of her husband while fulfilling his will, N. Polonska-Vasylenko handed over a collection of documents to the Department of Manuscripts in the Library of the Ukrainian Academy of Science (IP НБУВ, ф. 40, оп. 1, од. зб. 305, арк. 1). In the letter which she addressed to the director of the library it only comes about the manuscript materials to which M. Vasylenko was directly related. It was also noted that she herself had begun to compile a scientific description of the materials along her husband lifetime and she wanted to complete this work. So the materials will be given over to the library gradually "as the description of them is drafted and they are ready to be transferred" (IР НБУВ, ф. 40, оп. 1, од. зб. 305, арк. 1 зв.).

A modern researcher D. Vashchuk even suggests the existence of two proof copies of the collection: the first one contains the article by M. Slabchenko and the second one contains the article by P. Sosenko (Vashchuk, 2017: 311). However in our opinion it is unlikely. Most likely there was one (and hopefully there is) a proof-reading copy and the very first version of the collection i.e. with the article by M. Slabchenko. That is why L. Okinshevych wrote about the "mistake" in the "Encyclopedia of Ukraine" and that the work on the Kaptur Courts had not been published in the volume of the seventh "Proceedings" (Okinshevych, 1995: 44). He pointed out: "As far as I know the theme of the kaptur courts was not ended by 
P. Sosenko. And as a publisher of the collected papers I am better informed about its content. ... There was no work about the kaptur courts in the seventh volume" (Okinshevych, 1995: 44). There is no information about this article and in the preface that was prepared by M. Vasylenko (ІР НБУВ, ф.40, оп. 1, од. зб. 449, 6 арк.; Vasylenko, 2006: 448-451). According to the logics it contains the information about the article by M. Slabchenko related to the history of the Military General Court (ІР НБУВ, ф. 40, оп. 1, од. зб. 449, арк. 4-5), since most likely the preface was written to the first version of the collected papers.

Though there is an indirect (but an important) argument proving thesis related to the kaptur courts work existence. It is a remark in the memories of L. Okinshevych, where he notes: "The central place in the seventh volume took the monograph by M. Slabchenko about the General Court of the Hetmanate. It was a large one (160 pages)" (Okinshevych, 1995: 43). M. Vasylenko together with his colleagues decided to replace this article by "the part of P. Sosenko's work about the Kaptur Courts" (ЦДАМЛМ України, ф. 542, оп. 1, спр. 46, арк. 366). So P. Sosenko's work existed because those 160 pages had to be replaced in a short term and in the same size (!). The article of M. Slabchenko was simply cut out of the printed book and another article of the same size should be inserted instead".

The procedure for the academic papers submitting was changed by that time. In accordance with the new requirements, the article must undergo a preliminary censorship, i.e. as N. Polonska-Vasylenko pointed out "must be revised by somebody from a Communist Party Academy" (ЦДАМЛМ України, ф.542, оп. 1, спр. 46, арк. 366). As there was no such specialist in Kyiv, so the work was sent to Kharkiv. Who was a reviewer is not known currently, but the work was reviewed for almost a year. The reviewer approved the work but suggested some changes. What happened then is not entirely clear, perhaps P. Sosenko refused to make corrections, maybe there were other reasons, but the secretary of the Department did not let printing this article and all printed copies of the seventh issue were destroyed in 1930 (ЦДАМЛМ України, ф. 542, оп. 1, спр. 46, арк. 366).

However they were obviously short of time for the actual destruction of the collected papers. In so far as the publishing house of AUAS in November 12, 1931 will apply to the Commission: "In view of the printing house demand to unload its premises from the printed sheets of AUAS completed editions, publishing house asks to allow to stitch up issue VII of the Commission Proceedings" (IP НБУВ, ф. 40, оп. 1, од. зб. 244 , арк. 1). I.e. the printed version existed and the whole circulation was printed. But unfortunately it was destroyed.

First of all these projects have not been implemented because of the conditions that the AUAS came to be in the late $1920^{\mathrm{s}}$ and early $1930^{\mathrm{s}}$.

In 1928 after changing of the leadership of the People's Commissariat for Education as well as the decision to reform the Academy after its careful inspection (Rud'ko, 2012: 145), many academicians had to stop their own researches and continue to research in the "right" angle. At the beginning of 1928 the 
inspection of academic researching continued. It was noted in the conclusions: "the social and economic department is not enough developed ... In particular the study of the Soviet law is almost absent and in this area the main attention is paid to the study of the old law history. The ideological nature of the third department work (Social and Economic department - Author) proceeds mainly from these pre-revolutionary time disciplines and it is not connected with the new Marxist sociology at all" (ІР НБУВ, ф. 40, оп. 1, од. зб. 50, арк. 2 зв.). On October 7, 1930 at a regular meeting the results of the inspection as well as the comments on the functioning of the Commission were discussed. It was decided "to follow the Marxist method of research in its further work and to supplement the programs of researches with the themes from the history of the revolutionary era" (IР НБУВ, ф. 40, оп. 1, од. зб. 162-237, арк. 20). In accordance with the decision each of the researchers had to change their research plans though such changes did not always have a positive impact on the quality of work and the ultimate scientific product. In addition the requirement of criticism was set for all previous work of "bourgeois", "liberal" and "nationalist" historiography (Korpus mahdeburzkykh, 2000: 10). The Commission members along with their own researches had to engage actively in criticism and self-criticism. They had to analyze the works of Rostyslav Lashchenko, Mikhailo Hrushevsky, Mikhailo Slabchenko, Mykola Vasylenko and others "newly" in the so-called "right" perspective (IР НБУВ, ф.40, оп. 1, од. зб. 162-237, 123 арк.).

Therefore when Petro Sosenko made a report "Kaptur Court Process" at the meeting of the Commission in June 1931 then the first remark was that the work should be developed differently "in accordance with the requirements of the new methods". Both Mykola Vasylenko and Lev Okinshevych had noticed that the author wrote his work two years ago and since the theme of the kaptur court is new and there is a lot of material for its research, it is desirable to continue working in the light of the time new requirements (ІР НБУВ, ф.40, оп. 1, од. зб. 162-237, арк. 48-49).

All these fundamental changes in the areas of scientific activity, mass arrests of employees, and subsequently the liquidation of the Commission (by that time it was named the Commission for the Study of the History of Ukrainian Law Author) had a very negative impact on the fate of its academic achievements. A large number of prepared works had been destroyed; many projects had never been implemented as well as many manuscripts had been lost forever.

When visiting the priest Mykola Shchepanyuk, who had been prisoned on the territory of TEMLAG, P. Sosenko was arrested on April 13, 1933. For some time he was detained in the psychiatric department of the house for preliminary imprisonment then the case was suspended (Sokolovskyi, 1999: 198). His father $\mathrm{K}$. Sosenko concerned with the fate of his son and tried to help but all his attempts failed (U pivstolitnikh zmahanniakh, 1993: 610-611). In 1935 P. Sosenko was prosecuted for "The Case of the Counter-Revolutionary Fascist Organization of the 
Roman Catholic and Uniate Clergy on the Right Bank of Ukraine" (ЦДАГО України, ф. 263, оп. 1, спр. 66457, т. 2, арк. 1-26). On May 14, 1936 he was convicted by the NKVD of the USSR Special Meeting for 5 years of labor camps but while moving on the milestone, he fell ill hard and died on October 20. Currently the fate of his archive is unknown. He had a wife and children (Zaklyns'kyi, 1943: 2). But taking in consideration the situation in which they were after the arrest of their husband and father, we believe it is unlikely that they had kept his manuscripts and documents. The wife had to testify against her husband as it often happened in those days (Obvynuvalnyi vysnovok, 2003: 328).

As addenda to this article we publish the thesis of the promotional report which was prepared and made by Petro Sosenko in January 4, 1930 at the meeting of the Commission for the Study of the History of Western-Ruthenian and Ukrainian Law. This manuscript is stored in the Manuscript Institute of the V. Vernadsky National Library of Ukraine in Mykola Vasylenko's personal fonds (f. 40). This is a typewritten text with author's corrections. The application is printed in the original language.

\section{ARCHIVES}

ІР НБУВ - Інститут рукопису Національної бібліотеки України ім. В. I. Вернадського [Manuscript Institute of the V. Vernadsky National Library of Ukraine].

ЦДАГО України - Центральний державний архів громадських об’єднань України [Central State Archives of Public Organizations of Ukraine].

ЦДАМЛМ України - Центральний державний архів-музей літератури і мистецтв України [Central State Archives Museum of Literature and Art of Ukraine].

\section{BIBLIOGRAPHY}

Білокінь С. Про видання, заборонені на стадії верстки, або тиражі яких було знищено (1920-1941). До джерел. Збірник наукових праць на пошану Олега Купчинського з нагоди його 70-річчя. Київ-Львів, 2004, вип. 2, 554-602.

Василенко М. П. Передмова до сьомого випуску «Праць Комісії для виучування історії західно-руського та вкраїнського права». М. П. Василенко. Вибрані твори у трьох томах: Том 2. Юридичні праці. Упорядники: І. Б. Усенко (кер. колективу), Т. І. Бондарук, А. Ю. Іванова, Є. В. Ромінський. Відп. ред.: Ю. С. Шемшученко, І. Б. Усенко. Київ: ТОВ «Видавництво «Юридична думка»»; Видавничий дім «Академперіодика», 2006, 448-451. 
Ващук Д. Дослідження українського права литовської доби у «Працях Комісії для виучування історії західно-руського та вкраїнського права». Icmoріографічні дослідження в Україні. Київ: Інститут історії України НАН України, 2017, вип. 27, 306-333.

Діло, 1918, № 131, 13 червня.

Діло, 1924, № 253, 13 листопада.

Діло, 1929, № 2, 2 січня.

Заклинський Б. Ксенофонт Сосенко. Пам'яті невтомного працівника Бойківщини. Львівські вісті. Щоденник для дистрикту Галичини, 1943, 5 лютого, 2.

Корпус магдебурзьких грамот українським містам: два проекти видань20-х40-х років XX століття / Упорядники і автори дослідження Андрейцев В. І., Ульяновський В. І., Короткий В. А. Київ: Прайм, 2000, 214.

Мудрий М. В обіймах політики: Український таємний університет у Львові, 1921-1925 роки (До 90-річчя від створення). Вісник НТШ: інформаційне видання / Світова Рада Наукового товариства ім. Т. Шевченка. Львів, 2011, № 46, 36-41.

Наука й письменство. Львів, 1924, р. I, кн. 1, 128.

Обвинувальний висновок у «Справі контрреволюційної фашистської організації римо-католицького і уніатського духовенства на Правобережжі України». 2 квітня 1936 р. 3 архівів ВУЧК-ГПУ-НКВД-КГБ, 2003, № 2 (21), 320-337.

Окиншевич Л. Десять років праці Комісії для виучування історії західньоруського та українського права (1919-1929). Праці Комісії для виучування історії західньо-руського та українського права. Київ: 3 друкарні Всеукраїнської Академії Наук, 1929, випуск шостий, XI-XXX.

Окіншеви Л. Моя академічна праця в Україні. Наукове товариство ім. Шевченка. Мемуарна бібліотека НТШ. Львів: НТШ, 1995, число 2, 88.

Полонська-Василенко Н. Видання Всеукраїнської Академії наук у Києві, знищені більшовицькою владою (Бібліографічна нотатка). Українські бібліографічні вісті. Авгсбург: Накладом Товариства Прихильників УВАН, 1948, 51-53.

Полонська-Василенко Н. Історична наука в Україні за совєтської доби та доля істориків. Записки Наукового товариства ім. Шевченка. ПарижЧікаго, 1962. T. CLXXIII: Праці Історико-філологічної секції. Збірник на пошану українських учених знищених більшовицькою владою, 7-111.

Протоколи Комісії для виучування західно-руського та українського права 3 1-го червня року 1926 по 1 липня року 1927. Праці Комісії для виучування історії західньо-руського та вкраїнського права. Київ: 3 друкарні Української Академії Наук, 1927, випуск третій, 466-500. 
Рудько С. Науково-організаційна діяльність М. П. Василенка в радянський період. Наукові записки. Серія "Історичні науки". Острог: Національний університет “Острозька академія", 2012, вип. 19, 139-150.

Соколовський О. К. Церква Христова 1920-1940. Переслідування християн в СРСР. Київ: Кайрос, 1999, 338.

Сосенко П. Етнольогічні первні староукраїнського права (Досліди над первопочатками української правової культури). Наука й письменство. Львів, 1924, р. I, кн. 1, 23-42.

Сосенко П. Правно-історичний розвиток людських імен та назв і значіння метрикальних книг для історії права. Уваги з приводу книжки: Józef Widajewicz. Nazwiska i przezwiska ludowe: studium z dziejów wsi polskiej XVII i XVIII w. (Pamiętnik historyczno-prawny pod redakcią Przemyslawa Dąbkowskiego. Tom I, zeszyt 3. Lwów 1925). Праці Комісії для виучування історії західньо-руського та українського права. Київ: 3 друкарні Всеукраїнської Академії Наук, 1929, випуск шостий, 493-500.

Старченко Н. Каптуровий суд першого безкоролів'я крізь призму скарг (1572-1574). Український археографічний щорічник. Нова серія. К.: Український письменник, 2009, вип. 13/14, 265-283.

у півстолітніх змаганнях. Вибрані листи до Кирила Студинського (18911941) / Інститут української археографії АН України; Упоряд. О. Гайова; Упоряд., передмова У. Єдлінська; Упоряд. Г. Сварник. Київ: Наукова думка, 1993, 768.

Українські часописи Львова 1848-1939 рр.: Історико-бібліографічне дослідження: У 3 т. Т. 3, кн. 1. 1920-1928 рр. Львів: Світ, 2003, 909.

Усенко І.Б. Рукописна правнича спадщина Всеукраїнської Академії наук: гіркі втрати і архівні знахідки. Правова держава. Київ: Інститут держави і права ім. В. М. Корецького НАН України, 2013, вип. 24, 6-14.

\section{REFERENCES}

Bilokin', 2004 - Bilokin', S. (2004). Pro vydannia, zaboroneni na stadii verstky, abo tyrazhi yakykh bulo znyshcheno (1920-1941). Do dzherel. Zbirnyk naukovykh prats na poshanu Oleha Kupchynskoho z nahody yoho 70-richchia, (2), 554-602. [in Ukrainian].

Dilo, 1918 - Dilo (1918). 131. [in Ukrainian].

Dilo, 1924 - Dilo (1924). 253. [in Ukrainian].

Dilo, 1929 - Dilo (1929). 2. [in Ukrainian].

Korpus mahdeburzkykh, 2000 - Andreitsev, V. I., Ulianovskyi, V. I., \& Korotkyi, V. A. (Comps.). (2000). Korpus mahdeburzkykh hramot ukrainskym mistam: dva proekty vydan 20-40 rokiv XX stolittia. Kyiv: Vydavnytstvo "Praim". [in Ukrainian]. 
Mudryi, 2011 - Mudryi, M. (2011). V obiimakh polityky: Ukrains'kyi taiemnyi universytet u Lvovi, 1921-1925 roky (Do 90-richchia vid stvorennia). Visnyk NTSh: informatsiine vydannia, (46), 36-41. [in Ukrainian].

Nauka i pysmenstvo, 1924 - Nauka i pysmenstvo (1924). I/1. [in Ukrainian].

Obvynuvalnyi vysnovok, 2003 - Obvynuvalnyi vysnovok u «Spravi kontrrevoliutsiinoi fashystskoi orhanizatsii rymo-katolytskoho i uniats'koho dukhovenstva na Pravoberezhzhi Ukrainy». 2 kvitnia 1936 r. Z arkhiviv VUChK$H P U-N K V D-K H B, 2$ (21), 320-337. [in Ukrainian].

Okinshevych, 1995 - Okinshevy, L. (1995). Moia akademichna pratsia v Ukraini. Lviv: NTSh. [in Ukrainian].

Okynshevych, 1929 - Okynshevych, L. (1929). Desiat' rokiv pratsi Komisii dlia vyuchuvannia istorii zakhidno-rus'koho ta ukrains'koho prava (19191929). Pratsi Komisii dlia vyuchuvannia istorii zakhidno-rus'koho ta ukrains'koho prava, (6), XI-XXX. [in Ukrainian].

Polonska-Vasylenko, 1962 - Polonska-Vasylenko, N. (1962). Istorychna nauka v Ukraini za sovietskoi doby ta dolia istorykiv. Zapysky Naukovoho tovarystva imeni Shevchenka, (CLXXIII), 7-111. [in Ukrainian].

Polonska-Vasylenko, 1948 - Polonska-Vasylenko, N. (1948). Vydannia Vseukrains'koi Akademii nauk u Kyevi, znyshcheni bilshovytskoiu vladoiu (Bibliohrafichna notatka). Ukrainski bibliohrafichni visti, 51-53. [in Ukrainian].

Protokoly Komisii, 1927 - Protokoly Komisii dlia vyuchuvannia zakhidno-ruskoho ta ukrainskoho prava z 1-ho chervnia roku 1926 po 1 lypnia roku 1927. (1927). Pratsi Komisii dlia vyuchuvannia istorii zakhidno-rus'koho ta ukrains'koho prava, (3), 466-500. [in Ukrainian].

Rud'ko, 2012 - Rud'ko, S. (2012). Naukovo-orhanizatsiina diialnist M. P. Vasylenka v radianskyi period. Naukovi zapysky Natsionalnoho universytetu "Ostrozka akademiia". Seriia "Istorychni nauky", (19), 139-149. [in Ukrainian].

Sokolovskyi, 1999 - Sokolovskyi, O. (1999). Tserkva Khrystova 1920-1940. Peresliduvannia khrystyian $v$ SRSR. Kyiv: Kairos. [in Ukrainian].

Sosenko, 1924 - Sosenko, P. (1924). Etnolohichni pervni staroukrains'koho prava (Doslidy nad pervopochatkamy ukrains'koi pravovoi kultury). Nauka y pysmenstvo, I/1, 23-42. [in Ukrainian].

Sosenko, 1929 - Sosenko, P. (1929). Pravno-istorychnyi rozvytok liudskykh imen ta nazv i znachinnia metrykalnykh knyh dlia istorii prava. Uvahy z pryvodu knyzhky: Józef Widajewicz. Nazwiska i przezwiska ludowe: studium z dziejów wsi polskiej XVII i XVIII w. (Pamiętnik historyczno-prawny pod redakcią Przemyslawa Dąbkowskiego. Tom I, zeszyt 3. Lwów 1925). Pratsi Komisii dlia vyuchuvannia istorii zakhidno-rus'koho ta ukrains'koho prava, (6), 493-500. [in Ukrainian].

Starchenko, 2009 - Starchenko, N. (2009). Kapturowyi sud pershoho bezkorolivia kriz pryzmu skarh (1572-1574) [The Kaptur Court of the First Interregnum 
through the Prism of Complaints (1572-1574)]. Ukrainskyi arkheohrafichnyi shchorichnyk, (13/14), 265-283. [in Ukrainian].

U pivstolitnikh zmahanniakh, 1993 - Haiova, 0 (Comps.). (1993). U pivstolitnikh zmahanniakh. Vybrani lysty do Kyryla Studynskoho (1891-1941). Kyiv: Naukova dumka. [in Ukrainian].

Ukrainski chasopysy, 2003 - Romaniuk, M. M., \& Halushko, M. V. (Comps.). (2003). Ukrainski chasopysy Lvova 1848-1939 rr.: Istoryko-bibliohrafichne doslidzhennia. (Vol. 3, 1). Lviv: Svit. [in Ukrainian].

Usenko, 2013 - Usenko, I. (2013). Rukopysna pravnycha spadshchyna Vseukrains'koi Akademii nauk: hirki vtraty i arkhivni znakhidky [Handwritten legal legacy of the All-Ukrainian Academy of Sciences: bitter losses and archive finds]. Pravova derzhava, (24), 6-14. [in Ukrainian].

Vashchuk, 2017 - Vashchuk, D. (2017). Doslidzhennia ukrainskoho prava lytovskoi doby u «Pratsiakh Komisii dlia vyuchuvannia istorii zakhidnorus'koho ta vkrains'koho prava» [Research into Ukrainian Law in the Period of Grand Duchy of Lithuania Rule in the Collective Volume of Scientific Papers «The Committee`s Contributions for Studying the Eastern Russian and Ukrainian Law»]. Istoriohrafichni doslidzhennia v Ukraini, (27), 306333. [in Ukrainian].

Vasylenko, 2006 - Vasylenko, P. (2006). Peredmova do siomoho vypusku «Prats Komisii dlia vyuchuvannia istorii zakhidno-rus'koho ta vkrains'koho prava». Vybrani tvory u trokh tomakh: (Vol. 2. Yurydychni pratsi) Kyiv: TOV "Vydavnytstvo "Iurydychna dumka"'; Vydavnychyi dim "Akademperiodyka", 448451. [in Ukrainian].

Zaklyns'kyi, 1943 - Zaklyns'kyi, B. (1943, February 5). Ksenofont Sosenko. Pamiati nevtomnoho pratsivnyka Boikivshchyny. Lvivski visti. Shchodennyk dlia dystryktu Halychyny, p. 2. [in Ukrainian].

\section{ADDENDUM}

In addendum we add the "Theses of promotional work by P. Sosenko entitled "Origin of Kaptur Courts and Their Development at Right-Bank Ukraine in the 16th Century"'. The text is reproduced with the maximal adhering of the author stile features. Some typing gaps and technical mistakes were corrected without doubt. Punctuation is moved closer to the present norms. Explications of some terms and words have been added to the Sosenko's text. Underlining and emphasizing of some words are retained as it was in original text. 
Миколі Прокоповичу Василенку 1

\section{Тези до промоційної праці аспіранта П. К. Сосенка під заголовком: «Походження й розвиток каптурових судів на Правобережній Україні (XVI ст.)».}

Вступ. Приєднання Волині, Київщини та Брацлавщини 1569 р. до Польщі сталося через те, що економічні та політичні інтереси української шляхти збігалися з такими ж інтересами польської шляхти. Це приєднання вводило згадані українські землі у виімкове становище з правового та фактичного боку, - виімкове 1) в польській державі, 2) виімкове та ріжне поміж рештою українських земель.

В зв'язку з тим, цікаво простежити форми правопорядку на тих землях якраз у ті часи, коли вплив нового польського права бував меншій, а проявлялися б своєрідні форми та вияви правової думки населення тих земель. Одним з таких питань, на якому можна спостережувати ці моменти, це розвиток каптурових судів, бо вони бували під час безкоролів'я², а тоді в польській державі діяли самостійно окремі воєвідства.

Через виімкове становище згаданих земель дослід про каптурові суди не поширюється на всі українські землі в тодішній польській державі, а тільки на Волинь, Київщину і Брацлавщину. Хоч тема розпоряджає в переважній більшості матеріялом з Волині, а лише в незначній кількості з Київщини і Брацлавщини, - мимо цього дослід виявляє питання про каптурові суди в цілій Правобережній Україні, бо 1) Київський та Брацлавський матеріял пропав, а на підставі решток цього матеріалу досліду про ці землі все одно написати неможна; це ж знову було б не вигідно для історика українського права, відкриваючи перед його науково-дослідною перспективою на цьому місці пробіл; 2) між згаданими землями був живий правовий та економічний оборот і постійна виміна думок в справах каптурового судівництва.

Хронологічно тема обмежується XVI в., бо тоді зложилися основні форми каптурових судів, і ці форми стали за підставу для дальшого розвитку; подруге, якраз у XVI в. в розвиткові каптурових судів по окремих воєвідствах виявлялося найбільше своєрідних форм кожної землі, - отже й самостійної юридичної думки згаданих українських земель.

Тема вимагає такої будови, щоби питання про «каптур» і походження каптурових судів одкласти на кінець досліду, бо в той спосіб є змога оминути повторень матеріялу, а з другого боку сам дослід, розвиваючись і наближаючись до кінця, даватиме для повищих питань матеріял.

\footnotetext{
1 Написано олівцем.

2 Періоди безкоролів'я: 1572-1573, 1574-1576, 1586-1587.
} 


\section{Дослід:}

Зі смертю Жигмонта Августа 1572 р. по окремих воєвідствах почалися самочинні рухи шляхти з метою взяти в свої руки державний провід; у зв'язку з припиненням звичаєвих судів і під грозою надзвичайного часу, появляються для забезпечення тогочасного соціяльного ладу шляхетські надзвичайні суди, звані каптуровими. Ініціятива до створення тих надзвичайних судів вийшла від українських земель, а саме Белзського воєвідства, яке вже й до 1569 р. було під Польщею; звідціля думка перекинулася на Волинь i інші українські землі, а щойно через деякий час проявляється вона по воєвідствах властиво і Польщі.

Взагалі ж розвиток каптурових судів у XVI в. ішов знизу до верхів, від воєвідства до центру, а не з центру, як це було в деякій мірі в XVII і XVIII вв. під впливом генеральних конфедерацій.

Каптурові суди були установою новою, витвором окремих воєвідств, і то витвором самостійним тих воєвідств. Тому в початковому періоді розвитку каптурових судів (XVI в.) помітно кілька фаз розвитку, які з початку тривали коротше, а потім протягом тривання їхнього часу збільшувався.

Перша фаза розвитку каптурових судів характерна невизначеністю форм, і в ріжних воєводствах починається вона в ріжний момент часу. На Правобережній Україні вона тривала до кінця 1572 р. Початковою формою каптурових судів на Правобережній Україні був колегіяльний суд у складі: городський староста столичного міста воєводства (він же воєвода) та 5 депутатів од шляхти, хоч і з урядничими титулами. Але вони входили в склад суду каптурового не силою свого уряду, тільки з вибору, бо, напр., в складі каптурового суду був хорунжий землі, тоді, коли, наприклад, другий статут виразно забороняв хорунжому бути суддею.

Каптуровий суд у першій фазі розвитку міг судити або сам, або на широкому з'їзді шляхти, або й спільно з усім соймиком воєвідства.

Переломовою подією в розвитку каптурових судів була соймикова постанова-каптур 13/XII-1572 р. Від того часу каптурові суди емансипуються 3-під впливу старости столичного міста (воєводи), а стають судом виключно депутатським із суддями, яких вибирала сама шляхта.

Коли якийсь каптуровий суддя не міг брати участи в справі, або був неприсутній, то його засаджувано теж виборним депутатом, бо шляхта мала на меті в той спосіб мати контролю й стежити за безпекою своїх прав $\mathrm{i}$ привілеїв.

В особовому складі каптурового суду була встановлена певноозначена черга судового старшинства: перший з черги головував, в його неприсутности головував другий з черги і т. д.

Шляхта кожного повіту воєвідства старалася післати до складу каптурового суду своїх депутатів, щоб вони там стежили за кращою розв'язкою справ, що заіснували в обставинах, краще їм відомих. Розвиток каптурових 
судів характерний постійним зростом кількості каптурових суддів. Це теж було наслідком політичних прагнень шляхти, що дуже турбувалася за свої економічні вигоди й тому пильно стежила за незайманістю своїх прав і при кожній нагоді старалася мати вплив на свої інтереси через верховну державну владу, а коли звичайна верховна влада пригасала, то тоді взяти ту владу в свої руки. Писар у склад суду не входив, але завідував канцелярією каптурових судів і мав до помочи підписка (а може й більше підписків).

В першій фазі розвитку місце скликання залежало від місця побуту старости, що був тоді головою каптурового суду, або від місця, де відбувався соймик чи з'їзд шляхти. Властивою владою землі чи воєвідства під час безкоролів'я був соймик, але він делегував цю владу каптуровим депутатам, які з часом від судової влади перейшли й до інших форм влади.

В дальшому розвиткові місцем каптурових судів були столиці воєвідств Луцьк, Брацлав і Житомир. Але в бажаннях волинської шляхти щодо каптурового судівництва стали проявлятися сепаратистичні тенденції, особливо на Крем'янечині. Частинно це могло бути під впливом прикладу з Руського воєвідства, бо там каптурові суди були одного часу по окремих повітах; але назагал мабуть товкнули шляхту до цього особисті економічні інтереси. На чолі цього руху стояли князі Збаражські.

Крем'янецький сепаратистичний рух був самочинним виявом шляхетської самоволі, якої соймики воєвідства не санкціяновали, але цей рух мав той наслідок, що в каптуровому судочинстві в 1575 р. встановлено об'їзний спосіб одсуджування каптурових судів по головних містах повітових Луцьку, Володимирі та Кременці.

Час скликання каптурових судів був у різних фазах розвитку різний - що 3-6 тижнів. Це залежало від меншої чи більшої наладнаности каптурового судівництва та, мабуть, і від самого безпеченства в даному історичному моменті.

Територіяльно підлягали каптуровим судам справи тільки 3 даного воєвідства, де пізваний мав свою осілість і через те матеріяльну змогу в даній справі відповідати.

Територіяльно підлягали каптуровим судам всі особи з перерахованих у каптурах станів, які тільки мали на території даного воєвідства яким-небудь правним титулом свою осілість. Хто мав осілість в кількох воєвідствах, одповідав за вчинки скоїні в тих місцевостях перед каптуровими судами кількох воєвідств, і то рівночасно.

Хронологічно підлягали каптуровим судам справи, які заіснували від смерти короля й до коронації нового. Коронації як остаточний термін хронологічної підсудности встановлено на Волині ще з самого початку, тоді коли в польських воєвідствах за остаточний термін встановлювано спочатку обрання короля, а щойно в 3-му безкоролів'ї - коронацію. Ця ріжниця вказує, що шляхта українських воєвідств мала далеко більші політичні 
аспирації. Вона згоджувалася передавати свою судову владу тільки коронованому королеві, бо короновано ж тільки того короля, який підтверджував шляхетські привілеї, а лише аж сама коронація надавала королеві найвищу владу.

Особову підсудність перед каптуровими судами треба інакше розглядати як підсудність активну, а інакше - як підсудність пасивну. Активну підсудність перед каптуровими судами, безпосередню, мала в першу чергу шляхта, і взагалі тільки той, хто мав яким-небудь титулом свою осілість; так само пізвати перед каптуровий суд можна було тільки осілого даного воєвідства, але вислові в каптурів щодо каптурового суду міг удаватися кожний покривджений, - не можна розуміти як загальне правило про безпосередню активну підсудність всіх станів. Юридично каптури розуміли під тим тільки панів, які самі або через своїх правних заступників вели справи своїх підданих, хоч би покривдженими були й самі люди простого стану та понесли кривду теж од людей простого стану.

Однак не всі люди даного шляхетського стану завсіди та у всіх справах були підсудні каптуровому судові. (Докладніше визначують це тези до розділу про розмежування компетенції).

Зокрема каптуровим судам було підсудне все духівництво, а також особи з королівських маєтків. Опозиція в цьому напрямкові з боку римськокатолицького духівництва дала як наслідок мабуть тільки незначні відхилення від цієї засади.

До каптурових судів позивали також міщани [на] шляхту та духівництво, а з другого боку ставилися вони також на суд, коли позивали їх перед каптуровий суд шляхта або духівництво.

Основне завдання каптурових судів було забезпечити спокій і безпеченство, утримати статус-кво. В бік найбільшої небезпеки й неменучих потреб була звернена законодатна думка шляхти на протязі каптурових часів, яка при кожній нагоді зафіксовувала нові потреби й небезпеки клясового шляхетського життя в нових каптурах, додаючи до попередньої компетенціяльної бази нові вказівки й заборони, чи то знов її уточнюючи та поправляючи. Цим загальним поглядом і визначується річева компетенція каптурових судів.

3 початку розвитку каптурових судів річева компетенція обмежувалася карними, а потім цивільними правами й також злочинами, що порушували порядок каптурового судівництва; в останньому випадкові каптуровий суд діяв як наглий ${ }^{3}$ суд. Щойно пізніше каптурові суди розтягали свою компетенцію на адміністративні, скарбові та інші воєвідські справи й ставали через це виконкомом воєвідства під час безкоролів'я.

${ }^{3}$ Наглий - терміновий суд. 
Окремий порядок встановила була шляхта для каптурових часів для деяких справ. Це зроблено тому, щоби, з одного боку, не переобтяжувати каптурових судів, а з другого боку - загострити домініяльне 4 судівництво. Це були справи підданих, як також зловлених на гарячому вчинкові під час безкоролів'я.

В каптурових судах практика випереджувала постанови каптурів. Це не тільки торкалося самого процесу, але також і визначення компетенції каптурової. Багато справ, яких каптури не нормували зовсім, мимо цього припадали на каптурові суди, і наслідком того пізніші каптури ці справи нормували вже й окремими постановами. 3 наведеного видно, що в практиці каптурового судівництва відогравало свою ролю особливе каптурове звичаєве право.

Каптурове судівництво хоч і було надзвичайним судівництвом, але назагал воно не змінювало цілої клясової схеми станового судівництва, якій повинна була відповідати й схема судівництва в часи безкоролів'я. Коли за життя королів в тодішній польській державі кожний стан мав свої суди, в яких хоч і могли припадати справи людей іншого стану, але це було тільки в другу чергу, то й під час безкоролів'я такий порядок повинен був би залишитися. Припиняючи на час безкоролів'я звичайні шляхетські суди, шляхта встановлювала їм на зміну каптурові суди. Тому на каптурових судах повинні були припадати справи усіх інших станів остільки, оскільки вони припадали у гродських і земських судах; а не повинні були припадати перед каптуровим судом такі справи, в яких сторонами в процесі не виступала сама шляхта, або коли це не були випадки колізій права між особами ріжних станів, які в звичайний час припадали б перед гродським та земським судом. Наслідком цього, коли хоч одною з процесових сторін була особа шляхетського стану, то справа не могла припасти перед каптуровий суд, хіба в порядку наглости ${ }^{5}$.

Особи інших станів лише остільки, оскільки вони належали до шляхетського «рожаю», підлягали теж каптуровим судам. Так було з духівництвом, міщанами та євреями. Однак коли вони не мали шляхетства, то в справах між собою підлягали своїм становим судам, якщо не підлягали замковому присудові.

Зі смертю короля та з заведенням капутрових судів не припинявся біг процесових правних чинностей чи постанов, які заіснували ще за життя короля.

Припиняючи звичайні суди та запроваджуючи для своїх власних інтересів каптурові суди, - шляхта рівночасно не припиняла звичайного домі-

4 Домініальні суди, або приватні суди пана. Публічні суди над селянами, дорученні панові. Домініальні суди були вищою інстанцією для копних судів.

${ }^{5}$ Наглості - тобто терміновості. 
ніяльного судівництва. Через те й під час безкоролів'їв залишилися й всі наслідки цієї обставини. Коли, наприклад, в звичайний час справи о невчинення справедливости над підданим переходили за земськими позвами перед земський суд, то тепер такі справи стали переходити до каптурових судів. Якраз як наслідок домініяльного порядку судівництва треба пояснити ті випадки судових справ перед гродським урядом під час безкоролів'я, хоч каптури постановляли, що гродські та земські суди не діють. В даному випадкові це були справи не перед власним гродським судом, але справи, які випливали з домініяльно-старостинської юрисдикції, бо коли королівщинами відали королівські старости, то це був тільки інший вигляд домініяльности. Королівщина була майном короля, а під час безкоролів'я - майном держави й там староста заступав властию місце пана - феодала.

Крім справ в порядку домініяльно-старостинської юрисдикції припадали перед гродським (старостинським) урядом під час безкоролів'я ще справи неосілих, «як на тот час мешкаючи»; справи осіб, зловлених на крадіжі, на гарячому вчинкові. Послідовно мусіли теж припадати під час безкоролів'я перед гродським урядом справи о крадіж, задля яких потім одбувалося слідство, т. зв. «звод» 6 о річ крадену. Дальше припадали перед гродським під час безкоролів'я справи порядку арт. 4 розд. ХІІ7, як справи «виволанців», яких приловлено якраз в місцевостях, де були гродські уряди; справи євреїв перед підвоєводою або воєводою як перед «урядом жидовским», але це тому, що волинський воєвода був тоді якраз рівночасно й луцьким старостою; в кінці, можливо, що припадало перед гродським урядом слідство в справах вбивства.

Не діяли зовсім під час безкоролів'я земські та підкоморські судия, але підкоморий міг з доручення каптурового суду розсуджувати на місцях земельні справи й очивидячки каптуровому судові й не раз доводилося такий порядок практикувати.

Щодо міщан, то під час безкоролів'я розгляд справ у порядкові арт. 28 роз. 14 2-го стану залишався такий самий, бо й взагалі залишалося домініяльне судівництво. Справи 3 арт. 46, 47 розд. IV9 припадали на каптуровому суді. На міських судах мали залишатися справи міщан з міщанами та справи, коли міщани виступали як пізвана сторона від осіб іншого стану. Але така постановка міщанських справ дійсна тільки для двох перших безкоролів'їв, бо в 3-му безкоролів'ї шляхта повела, так би мовити, наступ, нама-

\footnotetext{
6 «Звід» являв собою процедуру розшуку особи, яка незаконно привласнила чужу річ, і повернення речі її власнику. Правила «зводу» регулювалися статтями 35-39 Поширеної редакції Правди Руської.

7 II Литовський статут.

8 Підкоморський суд - становий шляхетський суд для розгляду межових і земельних суперечок.

9 II Литовський статут.
} 
гаючись припинити міські суди; з другого боку, представники міських урядів старалися поставити цьому опір і продовжувати свою судову діяльність. Однак навіть припинення міських судів під час безкоролів'я не впливало зовсім на переведення справ у тому порядкові, який встановлював торунський статут з 1620 р. для безпеченства міст. Та назагал щодо міських судів, то не було під час безкоролів'я якоїсь твердої непохитної засади, бо через різність міщанського й шляхетського права та через незгідність економічних інтересів, - у цьому напрямку відбувалася боротьба.

На припиняли на час безкоролів'я своєї діяльности церковні суди, а 3 3-го безкоролів'я $\epsilon$ вістки про судову діяльність коронних рад. Це було наслідком цього, що центр старався опанувати самочинні воєвідські рухи та звести їх в одноцільне русло.

Назагал найважливішою ознакою розвитку каптурових судів $є 1$ ) зміни в організації їх особового складу, а 2) з другого боку, ступневе поширення компетенції на ріжні вже нові справи.

1575 р. на Волині (а в рр. 1573-1574 в польських воєвідствах припинено було діяльність каптурових судів, а привернено звичайні суди, хоч безкоролів'я ще не було закінчено). Історія цього моменту виявляє, з одного боку, ролю каптурових судів у приспішені розв'язки справи апеляційної реформи ${ }^{10}$, а $з$ другого боку, цей факт $є$ одним 3 доказів, що головною причиною припинення звичайних судів на час безкоролів'я була ця обставина, що через смерть короля не було до кого апелювати.

Каптурові суди були новиною в тогочасній системі судівництва. Їх встановлено в надзвичайний час та на швидку руку й тому в даних соймикових постановах шляхти про заведення каптурових судів було багато недокладностей та недоговорень. Наслідком цього була в Волинському воєвідстві завзята боротьба за такі дві нез'ясовані в каптурах справи, як справа за статут в каптуровому судівництві та за апеляцію від каптурових вироків. За ті дві справи волинська шляхта боролася тому, що в добровільному підчиненню сторони під вирок судді добачувано в тих часах радше підчинення особи під владу другої особи, ніж повинування судові як такому. В звичайний час рівноважником у цьому був король як найвищий суддя; - тепер же чимала група шляхти старалася перекинути ці обов'язки на соймик. Однак надзвичайність часу й сумаричність самого поступовання, що мала на меті приспішити вимір справедливости, вже в 1-му безкоролів'ї перехилили вирішення цієї боротьби в бік безапеляційності каптурових судів. Це було особливістю українських воєвідств, як воєвідств, що находилися у виімковому становищі, бо в польських воєвідствах щойно в 3-му безкоролів'ї

10 У 1578 р. сейм дозволив створити вищий шляхетський апеляційний суд - Коронний трибунал. 
конституція конвокаційного сойму в Варшаві признала вирокам каптурових судів силу трибунальских вироків, себто вироків остаточних.

Правне поступовання в каптурових судах залежало від висліду боротьби за статут і апеляцію. Тому що перші каптури з двох перших безкоролів'їв не давали каптуровим суддям виразної вказівки, яким правом вони б мали судити, то й в тому часі ми бачимо, з одного боку, в каптуровому судочинстві вільну руку каптурових суддів, а з другого боку - нарікання сторін. Однак каптурові судді вже й з початку не могли все ж таки зовсім не звертати увагу на статут, бо він давав зрештою готові вже приписи, що відповідали інтересам шляхти, а самі судді на швидку руку не могли придумати зовсім нового судочинства. Через те вони відступали від статутових прописів тільки там, де завдання приспішити процес давало їм підставу ці приписи на власну руку поправляти або змінювати. Тим більше мусіло так бути 3 хвилею, коли каптури вже виразно стали приписувати суддям, щоби вони судили згідно з статутом, а це починається від 27/VII-1574 p. Наслідком цього поступовання перед каптуровими судами не було дуже великих змін порівнюючи з правним поступуванням перед судами в звичайний час.

Скарги в каптуровий час характерні спеціяльними підкресленнями про надзвичайність каптурового суду, в якому скоїно злочин.

Позви спочатку виходили від імені гродського старости (воєводи), який стояв на чолі колегіяльного депутатського суду, а від 1573 р. - від імені самих депутатів, спочатку з їх особистими печатками, а пізніше - з печаткою воєводства: «печать речи посполитое воеводъства земъли волинъское». Цей напис виявляв дуже досадно обличчя української шляхти, що хоч і вважала своє воєвідство за окрему республіку, але задля своїх інтересів і не думала поривати з польською державою, бо національно-сепаратестичні тенденції були для неї далекі.

Каптуровий суд користувався не тільки з своєї канцелярії, але притягав для своїх дій також службово-канцелярський апарат гродських урядів.

Вручування позвів та визначування років до розправи носить на собі характер сумаричности. Рок у каптурових справах завжди був завитий ${ }^{11}$. Розправа відбувалася статутовим порядком.

Вирок грунтувався на доказах з справи й на приписах права. Обов'язкову ж силу мали каптури даного безкоролів'я, статут і ті закони, на які каптури вказували виразно. Вирок западав більшістю голосів, а окрема думка його не гальмувала. Але фактично часто переважала думка тих депутатів, які краще знали справу, або просто хотіли за неї постояти. В разі потреби каптуровий суд міг вирок одкласти з одного дня на другий і третій.

11 Завитий рок (zavitý rok, zawity rok) - строк, під час якого покликана сторона повинна обов'язково прибути. 
В декреті або відкладано справу, або звільнювано сторону від самого позву, або від позву й речи в ньому писаної; коли ж суд погоджувався з доказами поводової сторони, тоді задовольняв вимогу позву. Суд міг постановити або про заплату грошової суми на задовільнення позву, або про це, що противна сторона має виконати якусь чинність; за криваві ж вчинки була кара смерти на безпосередніх виновників, а на неприсутніх в такому випадкові - «виволання» зі всіма його наслідками.

За невиплату присудженої суми передбачувано примусове стягнення 3 майна присудженого 3 совітостю ${ }^{12}$, яка в ріжних фазах розвитку була ріжна.

Заплата суми або виконання декрету, починаючи від другого безкоролів'я, напевно, а мабуть і перед тим, мала бути «не по роком», але найдальше до двох неділь і означеному місці.

Відправу вироків з початку доручувано повітовим старостам. Коли повідомлення через ув'язчий каптуровий лист нічого не помагало, тоді староста або його заступник вирушав 3 повітовою шляхтою на примусове виконання вироків. Труднощі при виконанні вироку навіть у випадку повітового рушення, - примусили шляхту загострювати й удосконалювати ту справу в каптурах окремими постановами. Вже при кінці 2-го безкоролів'я відібрано владу виконування вироків від старост і передано її земському хорунжому, а від 3-го безкоролів'я починаючи каптуровий суд висилав задля виконання вироку з-поміж себе по двох судових виконавців, якими могли бути всі депутати. За ув'язнення виконавці, хто б вони не були, отримували ув'язче, видавали на це свій лист та подавали до каптурового уряду повідомлення 3 реєстром. Та поки виконавці їхали виконувати вирок, мали обов'язок повідомити сторону через возьного.

Питання про походження каптурових судів розпадається на три окремих питання: 1) чому припиняли під час безкоролів'я діяльність звичайні суди та відколи почався такий звичай, 2) чому заведено каптурові суди та чому вперше - 1572 р. 3) звідки взялася назва каптурових судів. Про перше питання в літературі панує погляд, що звичайні суди переставали діяти з тої причини, що їх виконувано іменем та повагою короля, отже що сама смерть короля припиняла суди. Нинішній дослід доповнює це питання з того боку, що припинення звичайних судів було не так і не тільки через саму смерть короля, як радше причиною була ця обставина - зі хвилею смерти короля не було до кого апелювати.

Представлений дослід підтверджує висновки польських дослідників, що безпосередньою причиною заведення каптурових судів була надзвичайність історичного моменту після смерти Жигмонта Августа. А ініціятива до

12 Совітость (совитость) - подвійна оплата шкоди або заруки, закладу, встановлена судом. 
заведення тих судів проявилася насамперед в тих воєвідствах, де шляхта мала, так би мовити, найкраще політичне виховання та розуміння своїх клясових інтересів та, з другого боку, де найбільше давалася відчувати надзвичайність історичного моменту.

Представлений дослід розходиться із дотеперішніми дослідниками в питанні про походження й значіння слова «каптур», хоч не претендує на остаточне вияснення цього слова, не маючи під рукою всего матеріялу 3 польських воєвідств. Зате призбираний мною немалий матеріял виявляє, що слово «каптур» вживалося в таких значіннях - насамперед 1) в значінні надзвичайного закону, з'їздової чи соймикової постанови, ухвали, устави або, одним словом, списаної постанови чи закону, ухваленого на соймику про заведення надзвичайного порядку особливо в судівництві; 2) в значінні - надзвичайного часу безкоролів'я; 3) в значінні «спису», себто первісносписаного закону; 4) в значінні надзвичайного трибуналу (каптурового суду), який покликувано для переведення цього надзвичайного порядку; 5) при поширенні компетенції каптуровий суд перетворюється фактично у виконавчий комітет воєвідства, а звідціля «каптур» означав уже й саму організацію, яка його покликала, себто соймик або, як хочуть деякі дослідники, для польських воєвідств - конфедерацію. Однак це останнє значіння мабуть найпізніше. 6) Можливо також, що деколи шляхта розуміла під словом каптур і час жалоби, але таке значіння - коли воно було - вже тоді могло випливати з неправильного розуміння слова «каптур».

На мою думку слово «каптур» було витвором т. зв. «кухонної латини», подібно як слово «лядум» та багато інших тогочасних слів. А походило б воно від латинського слова саріо ${ }^{13}$, вжитого в скороченій формі кон'югації $[\ldots]^{14}$ та в переносному значінні й значило б те, що має бути підпорядковано, або те, що шляхта повинна на себе перебрати; або просто - повзяття постанови, чи просто сама постанова, як це в дійсності й зустрічається в численних документах. В історичному ж розвиткові значінь слів «каптур», «спис», «конфедерація» $\epsilon$ виразна ріжниця.

Так само $є$ ріжниця між конфедерацькими та каптуровими судами, а саме: 1) хронологічна, 2) з історичної обстановки, 3) в спробі покликання до життя та в складі й формі самого суду, 4) в компетенції.

Розвиток каптурових судів носить на собі виразні сліди структури тогочасного соціального ладу. Шляхта покликала їх до життя для своїх інтересів, але в основному в нічому не змінювала ані соціяльної структури, ані самої схеми судівництва. Залишаючи на час безкоролів'я в силі домініяльне судівництво, бо воно охороняло якраз глибокі підстави тогочасного соціального ладу та шляхетські економічні інтереси, - шляхта через заведення нової

13 саріо - лат. «приймати».

14 Вписано від руки, не розбірливо. 
форми судів тільки загострювала охорону своїх інтересів. Інтереси шляхти були назагал у цілій польській державі такі самі, й шляхта українських воєвідств, розуміючи спільність інтересів, ані разу не скористала з безкоролів'я, щоби проявити з свого боку різкі національно-сепаратистичні тенденції. Це не сталося навіть тоді, коли каптурові суди через поширення своєї компетенції були фактично виконкомом, фактичним урядом землі чи воєвідства.

IР НБУВ, ф. 40, од. зб. 681. Сосенко П. К. Походження і розвиток каптурових судів на Правобережній Україні (XVI cm.). Тези [20 рр. ХХ ст.]. Машинопис з рукописними правками. 13 арк. 